\title{
PENGARUH KUALITAS PRODUK, HARGA, IKLAN TERHADAP KEPUTUSAN PEMBELIAN PADA DEALER MPM MOTOR MADIUN
}

\author{
Yuliana Sudarno dan Supri Wahyudi Utomo \\ Pendidikan Akuntansi IKIP PGRI MADIUN \\ Email: angelinayulia@ymail.com
}

\begin{abstract}
ABSTRAK
Penelitian ini bertujuan untuk mengetahui pengaruh kualitas produk harga, dan daya tarik iklan terhadap keputusan pembelian pada produk sepedamotor matic Honda dan menganalisis faktor yang paling dominan dalam mempengaruhi keputusan pembelian pada sepeda motor matic Honda di Dealer MPM Motor Madiun. Penelitian ini digunakan sampel berjumlah 155 konsumen dengan teknik probability sampling. Kemudian dilakukan analisis terhadap data-data yang diperoleh berupa analisis data kuantitatif dan dengan metode pengumpulan data berupa kuisioner. Analisiskuantitatif meliputi uji validitas dan uji reliabilitas, uji asumsi klasik, analisis dan regresi berganda. Hasil penelitian menunjukan bahwa: 1) kualitas produk berpengaruh signifikan terhadap keputusan pembelian sepeda motor matic Honda di Dealer MPM Motor Madiun, 2) harga tidak berpengaruh secara signifikan terhadap keputusan pembelian sepeda motor matic Honda di Dealer MPM Motor Madiun, 3) daya tarik iklan berpengaruh secara signifikan terhadap keputusan pembelian.
\end{abstract}

Kata Kunci: Kualitas Produk, Harga, Daya Tarik Iklan, Keputusan Pembelian.

\section{PENDAHULUAN}

Persaingan antar dunia bisnis dalam era globalisasi khususnya di dunia otomotif sangatlah ketat, karena produk-produk yang beredar dipasaran sangat beragam dengan desain yang unik, menarik dan tentunya mempunyai keunggulan-keunggulan lain jika di bandingkan dengan pesaing. Keadaan yang di alami pada saat ini menghadapkan para pelaku bisnis disemua bidang maupun produsen dapat menjadi pemenang dalam persaingan bisnisnya. Apabila perusahaan mampu menjaring pelanggan sebanyak-banyaknya tentu perusahaan tersebut dapat memperoleh keuntungan yang besar pula.

Pasar Indonesia diramaikan oleh persaingan pasar motor matic. Salah satunya yaitu motor matic merek Honda. Motor matic Honda memiliki tiga jenis, yaitu Vario, Beat, dan Scoopy. Honda matic Vario memiliki desain yang elegan dan berkesan mewah. Trend pertumbuhan pasar sepeda motor matic berkembang sangat pesat.

Kualitas produk yang ditawarkan oleh produsen memposisikan produk dibenak pelanggan untuk tetap menggunakan produk tersebut dan menjadikan pelanggan yang loyal terhadap produk tersebut. Kualitas berkaitan erat dengan kepuasan pelanggan. Kualitas memberikan dorongan khusus bagi pelanggan untuk menjalin ikatan relasi saling menguntungkan dalam jangka panjang dengan perusahaan. Ikatan emosional semacam ini memungkinkan perusahaan untuk memahami dengan seksama harapan dan kebutuhan spesifik pelanggan. Pada gilirannya, perusahaan dapat meningkatkan kepuasan pelanggan, dimana perusahaan memaksimumkan pengalaman pelanggan. Kepuasan pelanggan berkontribusi pada terciptanya keputusan membeli produk.

PT Mitra Pinasthika Mustika adalah salah satu dealer yang menjual sepeda motor khusus Honda. PT. Mitra Pinasthika Mustika menjual berbagai jenis, tipe dan lain-lain. PT. Mitra Pinasthika Mustika Menghadirkan Motor Matic dengan suatu keunggulan berupa radiator yang menyatu dengan mesin, selain design yang penuh gaya dan berkesan sporty untuk memenuhi keinginan konsumen Indonesia khususnya Madiun. Konsep utama dalam pengembangan Honda Matic Madiun adalah gabungan antara kenyamanan dan kesenangan 
dalam berkendara, yang bertujuan untuk menciptakan sebuah kesan skuter yang "Absolute Matic" dengan memberikan suatu nilai tambah bagi konsumen. Nilai-nilai dasar yang senantiasa dikembangkan dalam perusahaan MPM Motor Madiun yaitu, Kerjasama, Terbuka, Kreatif, Peduli, Penuh Gairah dan Selalu terdepan dalam kreativitas dan kepedulian terhadap pelanggan.

Strategi penetapan harga menjadi sangat menentukan bagi Honda di tengah persaingan yang begitu ketat dengan Yamaha. Harga yang ditetapkan oleh Honda harus mampu untuk memenuhi harapan konsumen terhadap kualitas produknya. Selain itu, kesesuaian manfaat yang diterima konsumen juga harus diperhatikan oleh Honda dalam penetapan harga tersebut. Penetapan harga yang salah dapat menjadi masalah serius bagi Honda, karena Yamaha akan selalu siap untuk mengambil konsumen yang kecewa dengan Honda. Secara tradisional, harga menjadi faktor yang paling dominan dalam keputusan pembelian. Namun, seiring dengan perbaikan kondisi ekonomi konsumen faktor non harga juga menjadi faktor yang penting dalam keputusan pembelian.

Berdasarkan latar belakang diatas maka peneliti tertarik untuk mengambil judul "Pengaruh Kualitas Produk, Harga, Dan Iklan Terhadap Keputusan Pembelian Sepeda Motor Matic Merek Honda Pada Dealer MPM Motor Madiun".

\section{TELAAH LITERATUR}

\section{Keputusan Pembelian}

Pengambilan keputusan konsumen menurut Nugroho J. Setiadi (2010: 332) adalah proses pengintegrasian yang mengombinasikan pengetahuan untuk mengevaluasi dua atau lebih perilaku alternatif, dan memili salah satu di antaranya. Hasil dari proses pengintegrasian ini ialah suatu pilihan, yang disajikan secara kognitif sebagai keinginan berperilaku.

Menurut Basu Swastha (2007: 81), faktor-faktor yang mempengaruhi keputusan pembelian konsumen sebagai berikut: 1) Kebudayaan, 2) Kelas sosial, 3) Kelompok referensi kecil, 4) Keluarga, 5) Pengalaman, 6) Kepribadian, 7) Sikap dan kepercayaan, 8) Konsep diri.

\section{Produk}

Produk menurut Tamrin abdullah (2012: 153) adalah segala sesuatu yang dapat ditawarkan ke pasar untuk mendapatkan perhatian, dibeli, dipergunakan, atau dikonsumsi dan yang dapat memuaskan keinginan atau kebutuan.

Menurut zulian yamit (2010: 10) mengungkapkan ada delapan dimensi kualitas produk, yaitu : 1) Kinerja (performance), 2) Fitur Produk, 3) Keandalan (reliability), 4) Kesesuaian dengan spesifikasi (conformance to specification), 5) Daya Tahan (durability), 6) Kemampuan diperbaiki (serviceability), 7) Keindahan (aestethic), 8) Kualitas yang dipersepsikan (perceived quality)

\section{Harga}

Definisi harga menurut Basu Swastha (2007: 147) adalah sejumlah uang (ditambah beberapa produk) yang dibutuhkan untuk mendapatkan sejumlah kombinasi dari produk dan pelayanannya. Dari definisi diatas dapat diketahui bahwa harga yang dibayar oleh pembeli sudah termasuk layanan yang diberikan oleh penjual. Banyak perusahaan mengadakan pendekatan terhadap penentuan harga berdasarkan tujuan yang hendak dicapainya. Adapun tujuan tersebut dapat berupa meningkatkan penjualan, mempertahankan market share, mempertahankan stabilitas harga, mencapai laba maksimum dan sebagainya.

Menurut Basu Swastha (2003: 242), tingkat harga dipengaruhi oleh beberapa faktor, diantaranya adalah : 1) Keadaan Perekonomian, 2) Permintaan dan Penawaran, 
3) Elastisitas Permintaan, 4) Persaingan, 5) Biaya, 6) Tujuan Perusahaan, 7) Pengawasan Pemerintah

\section{Iklan}

Menurut Monle Lee \& Carla Johnson (2011: 3), pengertian periklanan adalah komunikasi komersil dan nonpersonal tentang sebuah organisasi dan produk-produknya yang ditransmisikan ke suatu khalayak target melalui media bersifat massal seperti televisi, radio, koran, majalah, reklame luar ruang, atau kendaraan umum.

Menurut Basu Swasta (2003:369), tujuan periklanan bagi suatu barang akan tergantung pada tahap yang ada di dalam siklus keidupan produk tersebut. Biasanya, periklanan produk baru dilakukan untuk : a) Memberikan kesadaran pada pembelian tentang adanya produk baru tersebut, b) Mendorong distribusi merk baru, c) Menunjukan kepada pembeli dengan suatu alasan bagi pembelian produk tersebut.

\section{Hipotesis Penelitian}

H1 : Kualitas produk berpengaruh secara signifikan terhadap keputusan pembelian.

$\mathrm{H} 2$ : Harga berpengaruh secara signifikan terhadap keputusan pembelian.

H3 : iklan berpengaruh secara signifikan terhadap keputusan pembelian.

\section{METODE PENELITIAN}

\section{Populasi, Sampel dan Teknik Sampling}

Suharsimi Arikunto (2010: 173) berpendapat bahwa "populasi adalah keseluruhan subyek penelitian". Populasi disini yang dimaksudkan yaitu pengguna matic yang ada di Dealer MPM Motor Madiun sebanyak 254 pengguna Matic.

Penentuan sampel dilakukan deengan rumus (teknik solvin) yang dikutip oleh Syofian Siregar (2011: 149) sebagai berikut:

$$
\begin{gathered}
\mathrm{n}=\frac{\mathrm{N}}{1+\mathrm{N}(\mathrm{e})^{2}} \\
\mathrm{n}=\frac{254}{1+254(0.05)^{2}} \\
\mathrm{n}=\frac{254}{1+254(0.0025)} \\
\mathrm{n}=\frac{254}{1.635} \\
\mathrm{n}=155,352
\end{gathered}
$$

Teknik pengambilan sampel dalam penelitian ini dilakukan dengan menggunakan teknik non probabilitas, dengan model accidental sampling, accidental sampling adalah memilih secara kebetulan. Teknik ini dikatakan secara kebetulan karena penelitian memang dengan sengaja memilih sampel kepada siapa pun yang ditemuinya atau by accident pada tempat, waktu, dan cara yang telah ditentukan. 


\section{ANALISIS DATA}

Analisis data menggunakan program SPSS (Statistical Package for the Social Science) for windows versi 16.0, dengan tahap-tahap sebagai berikut:

a. Uji Kualitas Data

\section{Uji Validitas Instrument}

Imam Ghozali (2012: 52) berpendapat bahwa: "uji validitas digunakan untuk mengukur sah atau valid tidaknya suatu kuesioner". Valid berarti instrumen yang digunakan dapat mengukur apa yang hendak diukur. Variabel dikatakan valid jika $r$ hitung positif dan $r_{\text {hitung }}>r_{\text {tabel }}$. Variabel dikatakan tidak valid jika $r$ hitung tidak positif dan $r_{\text {hitung }}<r_{\text {tabel }}$ (Imam Ghozali, 2012: 53).

2 Uji Reliabilitas

Duwi priyatno (2010: 30) berpendapat bahwa: "uji reliabilitas yaitu untuk menguji konsistensi alat ukur, apakah hasilnya tetap konsisten jika pengukuran diulang. Instrumen kuesioner yang tidak reliabel maka tidak dapat konsisten untuk pengukuran sehingga hasil pengukuran tidak dapat dipercaya. Uji reliabilitas yang banyak digunakan pada penelitian yaitu menggunakan metode Croncbach Alpha $(\alpha)$. Suatu konstruk atau variabel dikatakan reliabel jika memberikan nilai Cronbach Alpha $>0,60$.

b. Uji Asumsi Klasik

1 Uji Normalitas

Imam Ghozali (2012: 164) berpendapat bahwa: "Uji statistik lain yang dapat digunakan untuk menguji normalitas residual adalah uji statistik non parametik Kolmogorov-Smirnov. Untuk menguji suatu data berdistribusi normal atau tidak, dapat diketahui dengan menggunakan grafik normal plot. Pada prinsipnya normalitas dapat dideteksi dengan melihat pendari residualnya.

2 Uji Multikoloniearitas

Imam Ghozali (2012: 105) berpendapat bahwa: "Uji multikolonieritas bertujuan untuk menguji apakah model regresi ditemukan adanya korelasi antar variabel bebas (independent)". Untuk mendeteksi ada atau tidaknya multikoloniaritas adalah dengan melihat nilai cutoff yang umum dipakai untuk menunjukkan adanya multikoloniaritas adalah nilai tolerance $\leq 0,10$ atau sama dengan nilai VIF varian infloating factor $\geq 10$. (Imam Ghozali 2012: 105).

3 Uji Heteroskedasitas

Cara untuk mendeteksi ada atau tidaknya heteroskedastisitas adalah dengan melihat grafik scartterplot antara nilai prediksi variable terikat/dependen (ZPRED) dengan residualnya (SRESID). Deteksi ada tidaknya heteroskedastisitas dapat dilakukan dengan melihat ada tidaknya pola tertentu pada grafik scatterplot antara ZPRED dan SRESID, dimana sumbu Y adalah sumbu yang telah diprediksi dan sumbu $X$ adalah residual yang telah diturdentized. (Imam Ghozali 2012: 139)

4 Autokorelasi

Imam Ghozali (2005: 95-96) berpendapat bahwa: "Uji auto korelasi bertujuan menguji apakah model regresi linier ada korelasi antara kesalahan pengganggu pada periode $\mathrm{t}$ dengan kesalahan pengganggu pada periode t-1 (sebelumnya)". Uji Durbin Watson (DW test) digunakan untuk autokorelasi tingkat satu dan mensyaratkan adanya intercept (konstanta) dalam model regresi dan tidak ada variabel lagi diantara variabel independen.

c. Analisis Linier Berganda

Persamaan regresi dapat dirumuskan sebagai berikut Sugiyono (2011: 275) :

$$
Y=a+b 1 X 1+b 2 X 2+b 3 X 3+\mathrm{e}
$$


Dimana:

$\begin{array}{ll}\mathrm{Y}^{\prime} & =\text { Keputusan Pembelian } \\ \mathrm{A} & =\text { Konstanta } \\ \mathrm{b}_{1}, \mathrm{~b}_{2} & =\text { Koefisien regresi } \\ \mathrm{X}_{1} & =\text { Kualitas Produk } \\ \mathrm{X}_{2} & =\text { Harga } \\ \mathrm{X} 3 & =\text { Daya Tarik Iklan }\end{array}$

d. Pengujian Hipotesis

1. Koefisien Determinasi $\left(\mathrm{R}^{2}\right)$

Imam Ghozali (2012: 97) berpendapat bahwa: "koefisien determinasi $\left(\mathrm{R}^{2}\right)$ pada intinya mengukur seberapa jauh kemampuan model dalam menerangkan variasi variabel dependen. Nilai koefisien determinasi adalah antara nol dan satu. Nilai $\mathrm{R}^{2}$ yang kecil berarti kemampuan variabel-variabel independen dalam menjelaskan variabel-variabel dependen amat terbatas.Uji Signifikansi Parsial (t-test)

2. Uji T (T-Test)

Duwi Priyatno (2010: 86) berpendapat bahwa: "Uji t digunakan untuk menguji pengaruh variabel independen secara parsial terhadap variabel dependen".

3. Uji Signifikasi Simultan (F test)

Duwi Priyatno (2010: 83) berpendapat bahwa: "Uji F digunakan untuk menguji pengaruh variabel independen secara bersama-sama terhadap variabel dependen".

\section{ANALISIS HASIL DAN PEMBAHASAN}

a. Uji Kualitas Data

1. Uji Validitas

Uji validitas dilakukan dengan bantuan software statistik yaitu SPSS 16.0. Dalam penelitian ini pengujian dilakukan terhadap 109 responden. Dengan pengambilan keputusan berdasarkan valid apabila $r^{\text {hitung }}>r^{\text {tabel }}$. Hasil uji validitas menunjukkan bahwa seluruh pernyataan untuk variable Kualitas Produk, Harga dan Iklan Teradap Keputusan Pembelian memiliki status valid.

2. Uji Reliabilitas

Uji reliabilitas dilakukan dengan bantuan software statistik yaitu SPSS 16.0. Dalam penelitian ini pengujian dilakukan terhadap 155 responden. Dengan dasar pengambilan keputusan jika nilai Cronbach Alpha lebih dari 0,60 dinyatakan reliabel. Adapun hasil pengolahan data terdapat pada tabel dibawah ini:

Tabel 1. Hasil Uji Reliabilitas

\begin{tabular}{lccc}
\hline \multicolumn{1}{c}{ Variabel } & Item & Nilai Alpha & Status \\
\hline Kualitas Produk & X1.1-X1.4 & 0,735 & Reliabel \\
Harga & X2.1-X2.4 & 0,681 & Reliabel \\
Daya Tarik Iklan & X3.1-X3.4 & 0,754 & Reliabel \\
Keputusan Pembelian & Y1.1-Y1.4 & 0,798 & Reliabel \\
\hline
\end{tabular}

Sumber: Data Primer yang diolah, 2013

Berdasarkan Tabel 5 di atas dapat terlihat bahwa seluruh variabel penelitian memiliki nilai Cronbach Alpha yang lebih besar dari 0.60 sehingga dapat disimpulkan bahwa semua variabel yang digunakan dalam penelitian ini berstatus reliabel. 
b. Uji Asumsi Klasik

1. Uji Normalitas

Berdasarkan hasil analisis dengan menggunakan program SPSS 16.0. Apabila pada gafik normal plot dapat terlihat jika data menyebar disekitar garis diagonal dan mengikuti arah garis diagonal, maka regresi memenuhi asumsi normalitas begitu pula sebaliknya.

Normal P-P Plot of Regression Standardized Residual

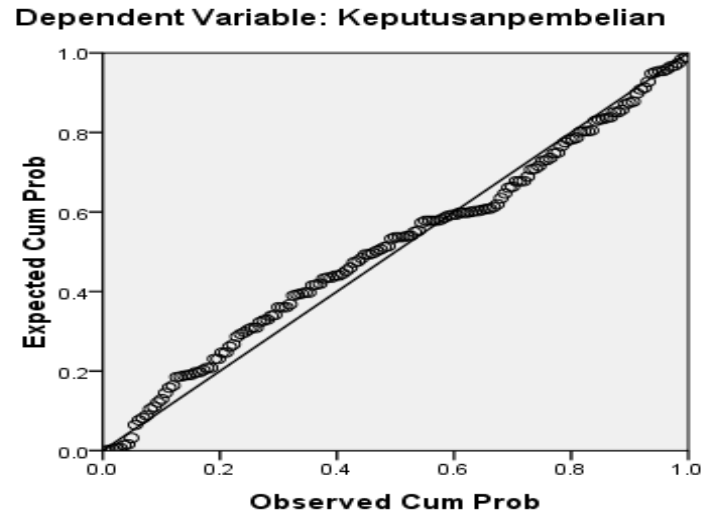

Jika dilihat berdasarkan grafik 1 di atas, maka dari semua data berdistribusi normal kerena semua data menyebar mengikuti garis diagonal dan mengikuti arah garis diagonalnya.

2. Uji Multikoloniearitas

Berdasarkan hasil analisis dengan menggunakan program SPSS 16.0. Untuk mendeteksi ada tidaknya multikolonieritas dalam model regresi dapat digunakan VIF dan lawannya Tolerance. Nilai cutoff yang biasa dipakai untuk menunjukkan adanya multikolonieritas adalah nilai Tolerance $\leq 0,10$ atau sama dengan nilai VIF $\geq 10$. Hasil pengujian menunjukkan bahwa semua variabel memiliki nilai VIF di atas 10, maka disimpulkan model regresi tersebut tidak terdapat problem multikolonieritas. Maka model regresi yang ada layak untuk dipakai.

3. Uji Heteroskedasitas

Berdasarkan hasil analisis dengan menggunakan program SPSS 16.0. Jika terdapat pola tertentu, seperti titik-titik yang ada membentuk pola tertentu yang terartur (bergelombang, melebar kemudian menyempit), maka mengindikasikan telah terjadi heteroskedastisitas dan begitu pula sebaliknya.

Gambar 1. Uji Scaterplots

Scatterplot

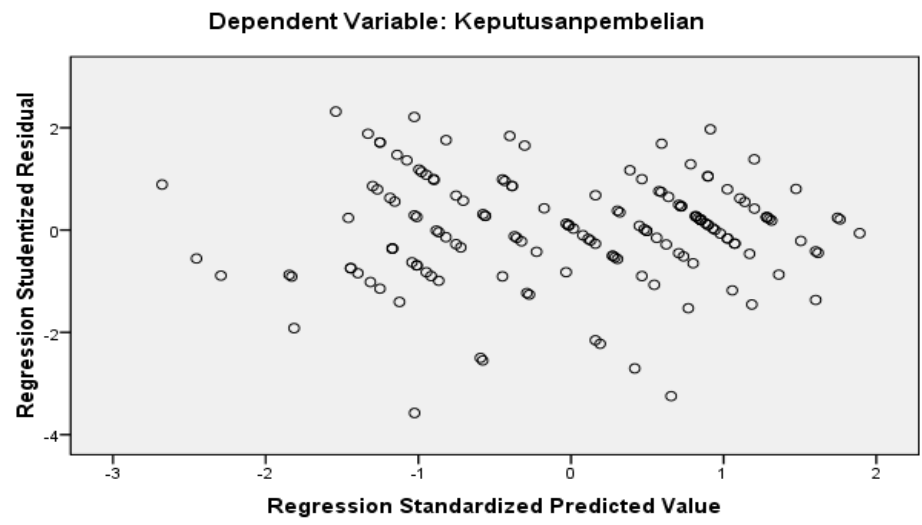


Dari grafik 2 di atas terlihat titik-titik yang menyebar secara acak, tidak membentuk suatu pola tertentu yang jelas, serta tersebar baik di atas maupun di bawah angka 0 pada sumbu Y. Sehingga modal regresi ini tidak terjadi heterokedastisitas dan layak dipakai untuk memprediksi minat nasabah.

4. Uji Autokorelasi

Hasil uji autokorelasi menunjukkan nilai DW hitung sebesar 1,889 sehingga dapat disimpulkan bahwa tidak terdapat masalah autokorelais dalma model regresi.

c. Pengujian Hipotesis

1. Koefisien Determinansi $\left(\mathrm{R}^{2}\right)$

Berdasarkan hasil analisis dengan menggunakan program SPSS 16.0. diperoleh hasil sebagai berikut:

\begin{tabular}{ccccc}
\multicolumn{5}{c}{ Tabel 2. Hasil Uji R } \\
\hline \multicolumn{5}{c}{ Model Summary } \\
\hline Model & $\mathrm{R}$ & R Square & Adjusted R & Std. Error of \\
1 & $.901^{\text {a }}$ & .811 & .807 & 1.064 \\
\hline
\end{tabular}

a. Predictors: (Constant), Daya tarik iklan, Harga, Kualitas produk

b. Dependent Variable: Keputusan pembelian

Dari Tabel 7 nilai koefisien determinasi yang disesuaikan (Adjusted $R^{2}$ ) adalah 0,807 artinya 80,7\% variabel independent dapat menerangkan variabel dependent.

2. Uji Signifikansi Parsial (t-test)

Berdasarkan hasil analisis dengan menggunakan program SPSS 16.0. diperoleh hasil uji t pada tabel 5, yang dapat dijelaskan sebagai berikut:

Tabel 3. Uji Regresi

\begin{tabular}{llrrrrr}
\hline & \multicolumn{7}{c}{ Standardized } \\
Model & & \multicolumn{7}{c}{ Unstandardized Coefficients } & \multicolumn{2}{c}{ Coefficients } \\
\hline 1 & (Constant) & 1.707 & .850 & & \multicolumn{1}{c}{ T } & \multicolumn{1}{c}{ Sig. } \\
& Kualitas produk & .630 & .062 & .624 & 10.076 & .047 \\
& Harga & -.034 & .038 & -.031 & -.889 & .376 \\
& Daya tarik iklan & .316 & .062 & .314 & 5.073 & .000 \\
\hline
\end{tabular}

Kualitas produk $\left(\mathrm{X}_{1}\right)$ berpengaruh signifikan terhadap keputusan pembelian $(\mathrm{Y})$, hal ini dapat dilihat dari probabilitas signifikansi untuk $\mathrm{X}_{1}$ sebesar 0,000 lebih kecil dari nilai alpha sebesar 0,05 . Sehingga kualitas produk berpengaruh signifikan terhadap keputusan pembelian. Hal ini berarti semakin tinggi tingkat kualitas produk, maka semakin tinggi pula tingkat keputusan pembelian.

Variabel harga $\left(\mathrm{X}_{2}\right)$ tidak berpengaruh signifikan terhadap keputusan pembelian (Y), hal ini dapat dilihat dari probabilitas signifikansi untuk $\mathrm{X}_{2}$ sebesar 0,376 lebih besar dari nilai alpha sebesar 0,05. Sehingga harga tidak berpengaruh signifikan terhadap keputusan pembelian. Hal ini berarti semakin tinggi tingkat harga terhadap konsumen, maka semakin rendah tingkat keputusan pembelian konsumen. Variabel daya tarik iklan $\left(\mathrm{X}_{3}\right)$ berpengaruh signifikan terhadap keputusan pembelian (Y), hal ini dapat dilihat dari probabilitas signifikansi untuk $\mathrm{X}_{2}$ sebesar 0,000 lebih kecil dari nilai alpha sebesar 0,05. Sehingga daya tarik iklan berpengaruh signifikan terhadap keputusan pembelian. Hal ini berarti semakin 
tinggi tingkat daya tarik iklan terhadap konsumen, maka semakin tinggi pula tingkat keputusan pembelian konsumen

3. Uji Signifikasi Simultan (F test

Berdasarkan hasil analisis dengan menggunakan program SPSS 16.0. diperoleh hasil sebagai berikut:

\begin{tabular}{lcccccc}
\multicolumn{7}{c}{ Tabel 4. Hasil Uji F } \\
ANOVA $^{\mathbf{b}}$ \\
\hline & Model & Sum of Squares & Df & Mean Square & F & Sig. \\
\hline 1 & Regression & 734.324 & 3 & 244.775 & 216.107 & $.000^{\mathrm{a}}$ \\
& Residual & 171.031 & 151 & 1.133 & & \\
Total & 905.355 & 154 & & \\
\multicolumn{7}{c}{ a. Predictors: (Constant), Daya tarik iklan, Harga, Kualitas produk } \\
b. Dependent Variable: Keputusan pembelian
\end{tabular}

Dari hasil perhitungan didapat nilai $\mathrm{F}^{\text {hitung }}$ sebesar 216,107 dan dengan tingkat keyakinan $155 \%, \alpha=5 \%$, df $1=3$, df $2(\mathrm{n}-\mathrm{k}-1)$ atau $(155-3-1=151)$, sehingga $\mathrm{F}^{\text {tabel }}$ diperoleh sebesar 2,66. Oleh karena itu $\mathrm{F}^{\text {hitung }}>\mathrm{F}^{\text {tabel }}(216,107>2,66)$, maka Ha diterima dan Ho ditolak. Kesimpulannya, variabel kualitas produk $\left(\mathrm{X}_{1}\right)$, harga $\left(\mathrm{X}_{2}\right)$ dan daya tarik iklan $\left(\mathrm{X}_{3}\right)$, berpengaruh signifikan terhadap keputusan pembelian $(\mathrm{Y})$, hal ini dapat dilihat dari probabilitas signifikansi untuk variabel independent sebesar 0,000 lebih kecil dari nilai alpha sebesar 0,05 . Sehingga kualitas produk $\left(X_{1}\right)$, harga $\left(X_{2}\right)$ dan daya tarik iklan $\left(\mathrm{X}_{3}\right)$ perpengaruh positif dan signifikan terhadap keputusan pembelian

\section{KESIMPULAN}

1. Kualitas produk berpengaruh positif dan signifikan terhadap keputusan pembelian. Kualitas produk yang lebih baik akan meningkatkan keputusan pembelian. Kualitas produk, menjadi topik utama dalam menciptakan kepuasan konsumen. Di satu sisi kepuasan menjadi faktor utama pada sebuah keputusan untuk pembelian suatu produk. Kualitas produk menjadi sebuah keharusan dalam menciptakan sebuah produk yang handal.

2. Persepsi harga tidak berpengaruh positif dan signifikan terhadap keputusan pembelian. Konsumen nampaknya akan menilai bahwa kelebihan harga yang ditawarkan oleh MPM Motor merupakan subtitusi dari sebuah kualitas produk yang diberikan oleh perusahaan. Namun demikian tidak dapat dipungkiri pula bahwa keberadaan harga yang terlalu mahal akan menjadi daya tolak yang besar oleh konsumen berkaitan dengan keputusan pembeliannya. Untuk itu penetapan harga nampaknya juga harus selalu dipantau.

3. Daya tarik iklan berpengaruh positif dan signifikan terhadap keputusan pembelian. Daya tarik iklan yang diberikan oleh MPM Motor Madiun dapat menarik konsumen untuk melakukan pembelian suatu produk. Hal ini berarti bahwa penyebaran iklan yang diberikan oleh MPM Motor Madiun telah meluas di daerah-daerah yang telah ditentukan.

\section{Saran}

1. Untuk memenangkan persaingan pasar, Dealer MPM Motor masih perlu meningkatkan kualitas produk yang ditawarkan. Khususnya dalam hal daya tahan dan keawetan mesin serta kenyamanan kendaraan saat dikendarai. Dengan kualitas produk yang semakin handal maka konsumen akan semakin yakin untuk membeli Motor Matic Honda.

2. Dalam hal strategi penetapan harga, dealer MPM Motor masih perlu mengkaji ulang dimana harga yang ditawarkan masih dianggap relatif tinggi dan dimata konsumen harga 
suku cadang masih dianggap relatif mahal. Dan hal-hal tersebutlah yang menjadi pertimbangan konsumen dalam membeli Motor Matic Honda.

3. Untuk kegiatan iklan perlu ditingkatkan khususnya dalam hal memperkenalkan produk dengan inovasi baru, dimana iklan yang telah diperkenalkan telah mampu menarik calon konsumen untuk membeli Motor Matic Honda. Selain itu pemberian bonus pembelian dan kegiatan pameran ditingkatkan agar calon konsumen semakin banyak yang mengenal dan tertarik untuk membeli Motor Matic yang dipasarkan oleh Dealer MPM Motor Madiun.

\section{DAFTAR PUSTAKA}

Basu Swastha dan Irawan. 2003. Manajemen Pemasaran Modern. Yogyakarta: Liberty.

Beni Ahmad Saebani. 2008.Metode Penelitian. Bandung: Pustaka Setia.

Duwi Priyatno. 2010. Teknik Mudah Dan Cepat Melakukan Analisis Data Penelitian Dengan SPSS. Yogyakarta: Gava Media.

Fandy Tjiptono. 2005. Prinsip-prinsip Total Quality Service. Yogyakarta: Andi Offset

Haryadi Sarjono. 2011. SPSS vs LISREL Sebuah Pengantar, Aplikasi Untuk Riset. Jakarta: Salemba Empat.

Imam Ghozali. 2005. Aplikasi Analisis Multivariate Dengan Program SPSS. Semarang: Universitas Diponegoro.

Imam Ghozali. 2012. Aplikasi Analisis Dengan Program IBM SPSS 20. Semarang: Universitas Diponegoro.

Kotler, Philip dan Lane Keller, Kevin. 2009. Manajemen Pemasaran. Terjemahan Bob Sabran. Jakarta: Erlangga.

Morissan,. 2010. Periklanan, Komunikasi Pemasaran Terpadu. Jakarta: Kencana.

Syofian Siregar. 2011. Statistika Deskriptif Untuk Penelitian. Jakarta: Rajawali Pers

Sugiyono. 2010. Metode Penelitian Pendidikan Pendekatan Kuantitatif, Kualitatif, Dan R\&D. Bandung: Alfabeta.

Sugiyono. 2011. Statistika Untuk Penelitian. Bandung: Alfabeta.

Suharsimi Arikunto. 2010. Prosedur Penelitian Suatu Pendekatan Praktik. Jakarta: Rineka Cipta. 


\title{
EVALUASI KINERJA SEKTOR PUBLIK TERHADAP KEPUASAN MASYARAKAT (STUDI KASUS PENERAPAN PNPM MANDIRI DI DESA JOGODAYUH KECAMATAN GEGER KABUPATEN MADIUN)
}

\author{
Frisca Fristyan Arinta Putri dan Isharijadi \\ Pendidikan Akuntansi IKIP PGRI MADIUN
}

\begin{abstract}
ABSTRAK
Penelitian ini bertujuan untuk mengetahui evaluasi dari kepuasan masyarakat di desa Jogodayuh Kecamatan Geger kabupaten Madiun terhadap kinerja sektor public pada program PNPM Mandiri. Sampel dalam penelitian ini yaitu seluruh populasi penelitian yang berjumlah 100 responden, yang diambil dari masyarakat desa Jogodayuh. Metode yang digunakan adalah metode penelitian kualitatif. Hasil penelitian ini menunjukkan bahwa evaluasi kinerja sektor publik yang terdapat di desa Jogodayuh menyatakan masyarakat desa Jogodayuh sangat puas terhadap kinerja dari PNPM Mandiri.
\end{abstract}

Kata Kunci: Evaluasi, Kinerja, Sektor Publik, Kepuasan Masyarakat

\section{PENDAHULUAN}

Organisasi sektor publik dipahami sebagai suatu entitas yang aktivitasnya berhubungan dengan usaha untuk menghasilkan barang dan pelayanan publik dalam rangka memenuhi kebutuhan dan hak publik. Organisasi sektor publik saat ini tengah menghadapi tekanan untuk lebih efisien, memperhitungkan biaya ekonomi dan biaya sosial, serta dampak negatif atas aktivitas yang dilakukan. Di setiap negara, cakupan organisasi sektor publik tidak sama. Tidak ada definisi yang komprehensif dan lengkap bisa digunakan untuk setiap pemerintah.

Mardiasmo (2002:2) organisasi sektor publik dipengaruhi oleh banyak faktor tidak hanya faktor ekonomi semata, akan tetapi faktor politik, sosial, budaya, dan historis juga memiliki pengaruh yang signifikan. Kompleksitas lingkungan organisasi sektor publik tidak seragam dan sangat heterogen. Demikian juga bagi stakeholder sektor publik, mereka membutuhkan informasi yang lebih bervariasi, handal, dan relevan untuk pengambilan keputusan.

PNPM Mandiri merupakan salah satu contoh dari organisasi sektor publik. PNPM singkatan dari Program Nasional Pemberdaya Masyarakat. PNPM Mandiri merupakan salah satu kegiatan bidang pemberdayaan masyarakat yang dibiayai oleh anggaran belanja bantuan sosial dalam APBN mengacu kepada kebijakan program penangulangan kemiskinan berbasis pemberdayaan masyarakat. PNPM Mandiri dilaksanakan melalui harmonisasi dan pengembangan sistem, mekanisme dan prosedur program, penyediaan pendampingan, dan pendanaan stimulan untuk mendorong prakarsa dan inovasi masyarakat dalam upaya penanggulangan kemiskinan.

PNPM-Pedesaan merupakan salah satu upaya untuk mempercepat upaya penanggulangan kemiskinan melalui pemberdayaan masyarakat untuk meningkatkan kesejahteraan dan kesempatan kerja di perdesaan, keputusan dan pengelolaan pembangunan.

Evaluasi yang memadai terhadap kinerja program diperlukan agar dapat mendorong pengelolaan program yang lebih efektif dan sesuai dengan tujuan PNPM Mandiri. PNPM Mandiri dengan formulasi koordinasi dan konsolidasinya tidak akan mungkin terlepas dari berbagai kekurangan, untuk itu hasil-hasil evaluasi sangat besar perannya dalam menyempurnakan formulasi program sehingga masyarakat miskin yang layak untuk dapat diwujudkan sehingga kepuasan masyarakat tercapai. 
Berdasarkan uraian diatas, penulis tertarik untuk melakukan penelitian dengan mengambil judul Evaluasi Kinerja Sektor Publik Terhadap Kepuasan Masyarakat (Studi Kasus Penerapan PNPM Mandiri di Desa Jogodayuh Kecamatan Geger Kabupaten Madiun). Berdasarkan latar belakang yang telah diuraikan di atas, maka permasalahan pokok dalam penelitian ini adalah: 1) Bagaimana konsistensi pelaksanaan PNPM Mandiri di Desa Jogodayuh?. 2)Bagaimana upaya yang harus dilakukan agar dapat meningkatkan kinerja program yang secara kolektif mencapai sasaran guna meningkatkan kepuasan masyarakat di Desa Jogodayuh?. 3)Adakah respon dan umpan balik pengelola program terhadap pengaduan dan saran publik dilakukan secara cepat dan tepat?

\section{TELAAH LITERATUR}

\section{Program Nasional Pemberdaya Masyarakat}

Program Nasional Pemberdaya Masyarakat (PNPM) merupakan program nasional dalam wujud kerangka kebijakan sebagai dasar dan acuan pelaksanaan program-program penanggulangan kemiskinan berbasis pemberdayaan masyarakat. Pemberdayaan masyarakat merupakan salah satu kebijakan bantuan sosial yang strategis dalam rangka mengurangi jumlah penduduk miskin, meningkatkan lapangan kerja, meningkatkan fasilitas pelayanan dasar, meningkatkan kesejahteraan rakyat, dan mendorong perkembangan daerah.

Tujuan PNPM-Mandiri terdiri dari dua tujuan yaitu tujuan uum dan tujuan khusus, adapun Tujuan umum adalah meningkatkan kesejahteraan dan kesempatan kerja masyarakat miskin secara mandiri. Sedangkan tujuan khusus terdiri dari: a). Meningkatkan partisipasi masyarakat, termasuk masyarakat miskin, kelompok perempuan, komunitas adat terpencil, kelompok masyarakat lainnya yang rentan dan sering terpinggirkan kedalam proses pengambilan keputusan dan pengelolaan pembangunan; b) Meningkatkan kapasitas kelembagaan masyarakat yang mengakar, representatif, dan akuntabel; c) Meningkkatkan kapasitas pemerintah dalam memberian pelayanan kepada masyarakat terutama masyarakat miskin melalui kebijakan, program dan penganggaran yang berpihak pada masyarakat miskin (pro-poor); d) Meningkatkan sinergi masyarakat, pemerintah daerah, swasta, asosiasi, perguruan tinggi, lembaga swadaya masyarakat, organisasi masyarakat, dan kelompok peduli lainnya, untuk mengefektifkan upaya-upaya penaggulangan kemiskinan; e) Meningkatkan keberdayaan dan kemandirian masyarakat, serta kapasitas pemerintah daerah, dan kelompok peduli setempat dalam menanggulangi kemiskinan diwilayahnya; f) Meningkatkan modal sosial masyarakat yang berkembang sesuai dengan potensi sosial dan budaya serta untuk melestarikan kearifan lokal; g) Meningkatkan inovasi dan pemanfaatan teknologi tepat guna, informasi dan komunikasi dalam pemberdayaan masyarakat.(Sri Lestari, 2012: 87)

\section{Organisasi Sektor Publik}

Di Setiap negara, cakupan organisasi sektor publik sering tidak sama. Tidak ada definisi yang komprehensif dan lengkap yang bisa digunakan untuk semua sistem pemerintahan. Area organisasi sektor publik bahkan sering berubah-ubah tergantung pada kejadian historis dan suasana politik yang berkermbang disuatu negara. Di Indonesia, berbagai organisasi termasuk dalam cakupan sektor publik antara lain pemerintahan pusat, pemerintahan daerah, sejmlah perusahaan di mana pemerintah mempunyai saham (BUMN dan BUMD), organisasi bidang pendidikan, organisasi bidang kesehatan, dan organisasiorganisasi massa (Mahsun, 2006: 10-11)

Menurut Lijan Poltak (2012: 182) organisasi sektor publik adalah organisasi yang berhubungan dengan kepentingan umum, penyediaan barang atau jasa kepada publik yang dibayar melalui pajak, retribusi dan pendapatan negara lainnya yang diatur melalui undangundang. Organisasi sektor publik bisa tidak lepas dari pemerintahan maka organisasi sektor 
publik identik dengan pemerintah. Meskipun sesungguhnya area organisasi sektor publik lebih luas dari sekedar pemerintahan

Menurut Harbani (2008:183) pengukuran kinerja pada dasarnya digunakan untuk penilaian kualitas atas keberhasilan atau kegagalan pelaksanaan kegiatan, program, dan/atau kebijakan sesuai dengan saaran dan tujuan yang telah ditetapkan dalam rangka mewujudkan misi dan visi instansi pemerintah. Penilaian kinerja merupakan evaluasi keberhasilan atau kegagalan seseorang dalam menjalankan tugasnya.

Menurut Mahsun (2013:25) pengukuran kinerja adalah suatu proses penilaian kemajuan pekerjaan terhadap tujuan dan sasaran yang telah ditentukan sebelumnya, termasuk informasi atas: efisiensi penggunaaan sumber daya dalam menghasilkan barang dan jasa; kualitas barang dan jasa (seberapa baik barang dan jasa diserahkan kepada elanggan dan sampai seberapa jauh pelanggan terpuaskan); hasil kegiatan dibandingkan dengan maksud yang inginkan; dan efektivitas tindakan dalam mencapai tujuan.

Menurut Mahsun (2013: 65) Evaluasi kinerja adalah kegiatan untuk menilai atau melihat keberhasilan dan kegagalan manajer publik dalam melaksanakan kegiatan dan fungsi yang diamanahkan kepadanya sebagai visi dan misi organisasi. Evalusi kinerja ini merupakan kegiatan lanjutan dari pengukuran kinerja sehingga dalam melakukan evaluasi kinerja harus berpedoman pada ukuran-ukuran dan indikator yang telah disepakati dan ditetapkan

Upaya memperbaiki kinerja organisasi layanan publik yang dilakukan secara terusmenerus pada akhirnya bisa dilihat manfaatnya. Beberapa manfaat yang harus bisa dihasilkan dalam perbaikan kinerja tersebut antara lain kesesuaian antara apa yang disediakan oleh organisasi sektor publik dengan kebutuhan para klien dan penguna jasa, adanya imbal balik yang sepadan dan efektif antara para wajib pajak dengan layanan pemerintah dan terciptanya keseimbangan dalam melayani kebutuhan masyarakat.

\section{Kepuasan Masyarakat}

Kepuasan masyarakat merupakan faktor yang sangat penting dan menentukan keberhasilan suatu badan usaha karena masyarakat adalah konsumen dari produk yang dihasilkannya. Pemerintah sebagai penyedia jasa layanan publik, harus senantiasa meningkatkan kualitasnya. Salah satu upaya untuk meningkatkan kualitas pelayanan publik, sebagaimana diamanatkan dalam Undang-undang Republik Indonesia Nomor 25 Tahun 2000 tentang Program Pembangunan Nasional (PROPENAS), perlu disusun indeks kepuasan masyarakat sebagai tolok ukur untuk menilai tingkat kualitas pelayanan.

Menurut Harbani Pasolong (2008: 145) kepuasan pelanggan adalah mencakup perbedaan antara harapan dan kenyataan atau hasil yang dirasakan. Kepuasan masyarakat terhadap organisasi publik sangat penting karena adanya hubungan kepercayaan masyarakat. Semakin baik kepemerintahan dan kualitas pelayanan yang diberikan, maka semakin tinggi pula kepercayaan masyarakat (high trust).

Menurut Philip Kotler dan Nancy Lee (2007: 188) kepuasan pelanggan merupakan fungsi dari harapan bukannya kinerja, bilamana memenuhi harapan maka pelanggan akan puas. Karena masyarakat tidak berharap banyak dari pemerintah.

Dalam kaitan ini masyarakat Desa Jogodayuh adalah pelanggan dari dana PNPMMPd, karena disini pelanggan adalah masyarakat yang dalam hal ini merupakan faktor penting di dalam organisasi sektor publik karena terdapat hubungan dengan masyarakat secara langsung. Dan masyarakat juga secara tidak langsung mengevaluasi terhadap pelayanan yang diberikan terhadap organisasi tersebut

Pelayanan publik adalah segala kegiatan pelayanan yang dilaksanakan oleh penyelenggara pelayanan publik sebagai upaya pemenuhan kebutuhan penerima pelayanan, maupun dalam rangka pelaksanaan ketentuan peraturan perundang-undangan. 
Organisasi sektor publik harus memenuhi dari adanya kebutuhan masyarakat nantinya, masyarakat dapat menilai kepuasan antara hasil dari kinerja organisasi itu sendiri dan program-program selanjutnya akan didukung penuh oleh masyarakat. Pada hakekatnya masyarakat adalah pelanggan bagi penyelenggara sektor publik. Apabila sektor publik itu PNPM, maka kebutuhan yang harus dipenuhi adalah adanya program yang sesuai dan yang dibutuhkan oleh pelanggan, baik dari kesehatan, pekerjaan, dan pendidikan . sehingga akan tercapainya MDGs yang menjadi studi kasus PNPM.

\section{RANCANGAN PENELITIAN}

Metode Penelitian penulis menggunakan desain penelitian kualitatif untuk mengetahui kepuasan masyarakat dari kinerja sektor publik (studi kasus PNPM-Mandiri di Desa Jogodayuh Kecamatan Geger Kabupaten Madiun) Penelitian dilakukan oleh penulis mulai bulan September 2013- Januari 2015. Dalam waktu kurang dari 5 bulan diharapkan dapat memperoleh data dan keterangan lainnya dari pihak yang terkait dalam penelitian ini.

Penelitian ini dilakukan dengan suatu metode agar bisa terselesaikan tepat waktu dan hasil yang diperoleh bisa dipertanggungjawabkan. Dalam penelitian ini menggunakan metode kualitatif, yakni suatu metode yang dalam penelitiannya berlandaskan filsafat postpositivisme, digunakan untuk meneliti kondisi objek yang alamiah. Metode ini juga menggunakan angka yang disebut metode kuantitatif karena data penelitian berupa angka-angka dan analisis menggunakan statistik (Sugiyono, 2012: 15). Jenis penelitian ini merupakan penelitian kualitatif yaitu penelitian yang digunakan untuk meneliti pada kondisi objek yang alamiah, (sebagai lawannya adalah eksperimen) dimana peneliti adalah sebagai instrumen kunci, pengambilan sampel sumber data dilakukan secara purposive sampling berupa data kualitatif sebagai pendukungnya seperti kata-kata atau kalimat yang tersusun dalam angket kalimat hasil konsultasi atau wawancara antara peneliti dan informan.

\section{TEKNIK ANALISIS DATA}

Dalam penelitian ini menggunakan pedoman pemantauan dan evaluasi PNPM Mandiri Perdesaan untuk menganalisis data yang diperoleh antara lain yaitu:

1. Evaluasi Keluaran (output) Evaluasi keluaran dilakukan untuk melihat sejauh mana perubahan kesejahteraan yang terjadi dengan membandingkan kondisi saat ini dari warga miskin dan kelompok pasaran lainnya dengan setelah berjalannya program (tahunan). Dasar pengukuran dan evaluasi ini dari hasil survei dasar yang dilakukan oleh para konsultan program sektor. Evaluasi ini dapat dilakukan dengan berbagai pihak, baik penanggung jawab program maupun pihak-pihak lain secara independen masukan evaluasi dapat disampaikan kepada penanggung jawab program diwilayahnya masingmasing dan atau kepada PNPM Mandiri Nasional.

2. Survei Dampak (impact) PNPM Mandiri merencanakan beberapa evaluasi dampak dengan fokus pada dampak kaitannya dengan penanggulangan kemiskinan, perkembangan kapasitas. Untuk maksud tersebut digunakan metode campuran baik kualitatif maupun kuantitatif. Sejumlah survei juga akan dilakukan untuk mengukur dampak program, dengan menggunakan survei Rumah Tangga, SUSENAS Survei Sosial Ekonomi Nasional) dan studi kualitatif. Keseluruhan survei ini menggunakan teknik perbedaan ganda dengan melihat kondisi sebelum dan sesudah, wilayah perlakuan dan wilayah kontrol.

3. Studi Kasus tematik Studi kasus disini meliputi penerapan PNPM Mandiri yang terdapat di Desa Jogodayuh dan mencakup antara lain sebagai berikut:

a. Kajian cepat prasarana fisik, untuk mengevaluasi mutu infrastruktur yang dibangun dengan standar PNPM 
b. Pengkajian operasional dan perawatan, untuk mengevakuasi tata cara operasional dan perawatan infrastruktur dan mengevaluasi stuktur ongkos yang dibayar pengguna kemampuan warga desa dan pemerintah setempat membiayai perawatan.

c. Pengkajian dampak ekonomi dan tingkat pengembalian, engembnagan kredit mikro dan usaha masyarakat, untuk mengevaluasi strategi kredit mikro dan pengembalian usaha dibawah PNPM, guna mengetahui bagaimana komponen-komponen ini dapat ditinggalkan agar mengahsilkan manfaat ekonomi yang lebih besar dan berkelanjutan.

d. Pengkajian ulang gender, mengkaji ulang strategi program dan pelaksanaan program dari aspek kesetaraan gender.

e. Pengkajian perencanaan pembangunan, mengevaluasi perencanaan mulai tingkat desa/kelurahan hingga Nasional dan bagaimana meningkatkan koordinasi antar berbagai tingkat.

f. Pengkajian pengembangan kapasitas kelembagaan, salah satu komponen penting PNPM program ini memberikan berbagai pelatihan bagi warga desa/kelurahan. Kelembagan masyarakat pelaksanaan program dan aparat Pemda setempat perkembngan komponen pengembngan kapasitas ini dampaknya terhadap penguatan kemandirian masyarakat perlu dinilai sebagi salah satu keberhasilan pelaksanaan PNPM Mandiri

g. Pengkajian pencapaian Millenium Development Goals (MDGs), diharapkan juga berdampak pada penerapan MDGs melalui evaluasi sektor terkait kegiatan pelayanan dasar seperti pendidikan dan kesehatan diharapkan dapat memberikan masukan bagi kebijakan pelayanan pelayanan dasar pada mut, investasi kesinambungan, kepuasan masyarakat, efektivitas biaya dan hubungan dengan pemwerintah setempat.

\section{PEMBAHASAN}

\section{Variabel Kinerja Pelaksanaan Program}

Untuk mengetahui kinerja pelaksanaan program dan tingkat kepuasan masyarakat peneliti menggunakan interval sebagai berikut:

Tabel 1. Interval Variabel kinerja pelaksana program

\begin{tabular}{ccccc}
\hline $\begin{array}{c}\text { Nilai } \\
\text { persepsi }\end{array}$ & $\begin{array}{c}\text { Nilai } \\
\text { Inteval IKM }\end{array}$ & $\begin{array}{c}\text { Nilai Interval } \\
\text { Konversi } \\
\text { IKM }\end{array}$ & $\begin{array}{c}\text { Mutu } \\
\text { Kinerja }\end{array}$ & $\begin{array}{c}\text { Kinerja Pelaksana } \\
\text { Program }\end{array}$ \\
\hline 1 & $0,00-0,99$ & $1-20$ & E & Sangat Tidak Baik \\
2 & $1,00-1,99$ & $21-40$ & D & Tidak Baik \\
3 & $2,00-2,99$ & $41-60$ & C & Cukup Baik \\
4 & $3,00-3,99$ & $61-80$ & B & Baik \\
5 & $4,00-4,99$ & $81-100$ & A & Sangat baik \\
\hline
\end{tabular}

Sumber: http://kpp.jatimprov.go.id/perpem/3.pdf (diunduh: Januari 2014)

Berdasarkan interval diatas maka hasil penelitian untuk kinerja tiap item adalah sebagai berikut:

Berdasarkan hasil perhitungan kinerja PNPM-MPd desa Jogodayuh maka dapat dilihat dari tabel dibawah ini, terdapat unsur kinerja dan nilai unsur kinerja. Untuk mendapatkan nilai rata-rata per unsur kinerja dengan cara menjumlahkan (kebawah) nilai masing-masing unsur kinerja sesuai dengan jumlah kuisioner yang diisi oleh responden, kemudian untuk nilai ratarata per unsur kinerja, jumlah nilai masing-masing unsur pelayanan dibagi dengan jumlah responden yang mengisi. Untuk mendapatkan nilai bobot rata-rata tertimbang dengan cara 
Frisca Fristyan Arinta Putri Dan Isharijadi : Evaluasi Kinerja Sektor Publik Terhadap...

$$
\frac{\text { Jumlah Bobot }}{\text { Jumlah Unsur }}=\frac{1}{8}=0,12
$$

Untuk menemtukan nilai dasar dalam nilai IKM setelah dikonversi yaitu untuk mendapatkan penilaian tersebut yaitu antara 25-100 maka hasil penilaian tersebut harus dikonversikan dengan nilai dasar 25.

Tabel 2. Hasil perhitungan kinerja PNPM-MPd.

\begin{tabular}{llc}
\hline NO & \multicolumn{1}{c}{ UNSUR KINERJA } & $\begin{array}{c}\text { NILAI UNSUR } \\
\text { KINERJA }\end{array}$ \\
\hline 1 & $\begin{array}{l}\text { Kepala Desa memberikan informasi secara } \\
\text { menyeluruh menyeluruh mengenai PNPM-Mandiri }\end{array}$ & 3,98 \\
2 & $\begin{array}{l}\text { Pelaksanaan kegiatan di pegang oleh warga Desa } \\
\text { Jogodayuh }\end{array}$ & 4,55 \\
3 & $\begin{array}{l}\text { Ketua pelaksana Anda melakukan instruksi yang } \\
\text { jelas pada anda setiap melakukan pekerjaan tanpa }\end{array}$ & 3,92 \\
& $\begin{array}{l}\text { ada pemahaman ganda } \\
\text { Ketua pelaksana Anda menunjukkan hal-hal yang } \\
\text { menarik minat kerja }\end{array}$ & 3,49 \\
Adanya pemanfaatan POLINDES sesuai dengan & 4,88 \\
6 & $\begin{array}{l}\text { Pekerjaan di selesaikan dengan jadwal program } \\
\text { Bunga SPP dibahas secara kelompok tanpa merasa } \\
\text { ada yang dirugikan }\end{array}$ & 4,53 \\
8 & $\begin{array}{l}\text { Kaum perempuan diberikan andil dalam penyetaraan } \\
\text { gender }\end{array}$ & 4,08 \\
\end{tabular}

Sumber: data angket responden. Diolah 2013

Untuk mengetahui nilai indeks unit pelayanan dihitung dengan cara berikut:

$(3,98 \times 0,12)+(4,55 \times 0,12)+(3,92 \times 0,12)+(3,49 \times 0,12)+(4,88 \times 0,12)+(4,53 \times 0,12)+$ $(4,08 \times 0,12)+(4,16 \times 0,12)=3,98$

Dengan demikian hasil indeks pelayanan hasilnya dapat disimpulkan sebagai berikut:

a. Nilai IKM setelah dikonversi $=$ Nilai Indeks X Nilai dasar $=3,98$ X 25 $=9,95$

b. Mutu Kinerja A. Dilihat dari tabel 5.1 nilai interval yang dikonversi 9,95 maka mutu kinerja A dan kinerja pelaksanaan program Sangat Baik.

c. Kinerja pelaksanaan program PNPM-MPd di Desa Jogodayuh Sangat Baik

Dari data tersebut dapat dilihat kinerja dari pengelolaan program berjalan dengan sangat baik sesuai rencana yang sudah ditetapkan oleh Tim pelaksana atas pencapaian program yang dilaksanakannya. Sehingga program yang telah dijalankan PNPM-MPd didesa Jogodayuh pada periode 2012/2013 mencapai hasil yang sangat baik bagi masyarakat.

\section{Variabel kepuasan masyarakat atas pencapaian program}

Tingkatan kepuasan masyarakat diukur setelah tercapainya program PNPM-MPd desa Jogodayuh pada periode 2012/2013 maka untuk mengetahui tingkat kepuasan terhadap pelaksanaan program, maka peneliti menggunakan interval sebagai berikut: 
Tabel.3 Interval variabel Kepuasan Masyarakat terhadap PNPM-MPd

\begin{tabular}{cccc}
\hline $\begin{array}{c}\text { NILAI } \\
\text { PERSEPSI }\end{array}$ & $\begin{array}{c}\text { NILAI } \\
\text { INTERVAL } \\
\text { IKM }\end{array}$ & $\begin{array}{c}\text { NILAI } \\
\text { INTERVAL } \\
\text { KONVERSI IKM }\end{array}$ & $\begin{array}{c}\text { KEPUASAN } \\
\text { MASYARAKAT }\end{array}$ \\
\hline 1 & $0,00-0,99$ & $1-20$ & Sangat Tidak Puas \\
2 & $1,00-1,99$ & $21-40$ & Tidak Puas \\
3 & $2,00-2,99$ & $41-60$ & Cukup Puas \\
4 & $3,00-3,99$ & $61-80$ & Puas \\
5 & $4,00-4,99$ & $81-100$ & Sangat Puas \\
\hline
\end{tabular}

Sumber: http://kpp.jatimprov.go.id/perpem/3.pdf (diunduh: Januari 2014)

Berdasarkan interval maka hasil dari penelitian unsur untuk kepuasan masyarakat tiap item adalah:

Berdasarkan hasil perhitungan kinerja PNPM-MPd desa Jogodayuh maka dapat dilihat dari tabel dibawah ini, terdapat unsur kinerja dan nilai unsur kinerja. Untuk mendapatkan nilai rata-rata per unsur kinerja dengan cara menjumlahkan (kebawah) nilai masingmasing unsur kinerja sesuai dengan jumlah kuisioner yang diisi oleh responden, kemudian untuk nilai rata-rata per unsur kinerja, jumlah nilai masing-masing unsur pelayanan dibagi dengan jumlah responden yang mengisi. Untuk mendapatkan nilai bobot rata-rata tertimbang dengan cara

$$
\frac{\text { Jumlah Bobot }}{\text { Jumlah Unsur }}=\frac{1}{8}=0,12
$$

Untuk menemtukan nilai dasar dalam nilai IKM setelah dikonversi yaitu untuk mendapatkan penilaian tersebut yaitu antara 25-100 maka hasil penilaian tersebut harus dikonversikan dengan nilai dasar 25.

Tabel 4. Hasil Perhitungan kepuasan Masyarakat Desa Jogodayuh

\begin{tabular}{|c|c|c|}
\hline NO & UNSUR KEPUASAN & $\begin{array}{l}\text { NILAI UNSUR } \\
\text { KEPUASAN }\end{array}$ \\
\hline 1 & Bagaimana hasil kinerja pelaksana PNPM & 4,28 \\
\hline 2 & $\begin{array}{l}\text { Bagaimana menurut Anda tentang } \\
\text { kesetaraan gender dalam Simpan Pinjam } \\
\text { Perempuan }\end{array}$ & 4,31 \\
\hline 3 & $\begin{array}{l}\text { Bagaimana pendapat Anda tentang } \\
\text { kemampuan petugas dalam memberikan } \\
\text { pengarahan pada saat musyawarah }\end{array}$ & 3,90 \\
\hline 4 & $\begin{array}{l}\text { Bangunan bisa dimanfaatkan dengan baik } \\
\text { setelah adanya serah terima }\end{array}$ & 4,10 \\
\hline 5 & $\begin{array}{l}\text { Anggota SPP akan diuntungkan dengan } \\
\text { adanya bunga yang relatif rendah }\end{array}$ & 4,18 \\
\hline 6 & $\begin{array}{l}\text { Bagaimana pendapat Anda adanya } \\
\text { kemudahan dalam penyeleksian bagi calon } \\
\text { anggota SPP }\end{array}$ & 4,42 \\
\hline
\end{tabular}

Sumber: Data angket responden. Diolah:2013 
Untuk mengetahui nilai Indeks Kepuasan dihitung dengan cara berikut:

$(4,28 \times 0,16)+(4,31 \times 0,16)+(3,90 \times 0,16)+(4,10 \times 0,16)+(4,18 \times 0,16)+(4,42 \times 0,16)=3,99$

Dengan demikian nilai indeks unit pelayanan hasilnya dapat disimpulkan sebagai berikut:

a. Nilai IKM setelah dikonversi $=$ Nilai Indeks X Nilai Dasar $=3,99$ X25 $=9,975$

b. Mutu Pelayanan A. Dilihat pada tabel 5.3 nilai interval IKM 9,975 yaitu berada nilai persepsi nomor 5 dan nilai interval IKM 4,00-4,99 dan nilai interval konversi IKM antara 81-10 dengan kepuasan masyarakat yang menyatakan Sangat Puas.

c. Kepuasan masyarakat dari terlaksana program/proyek PNPM-MPd adalah sangat Puas

Dari data tersebut dapat dilihat bahwa masyarakat merasa Sangat Puas dengan pembangunan yang sudah dikerjakan oleh tim pelaksana Program PNPM-MPd di desa Jogodayuh pada periode 2012/2013.

\section{KESIMPULAN DAN SARAN \\ Kesimpulan}

Berdasarkan hasil penelitian pada PNPM-MPd di Desa Jogodayuh terutama hasil dari evaluasi kinerja sektor publik dalam kaitan mengenai kepuasan masyarakat, dan ditinjau dari proses evaluasi dokumen, wawancara, observasi, dan berbagai dokumentasi, maka penulis dapat menarik kesimpulan sebagai berikut:

1. Desa Jogodayuh untuk tiap tahunnya selalu berperan aktif dengan mendapatkan ranking pada tiap program dan PNPM-MPd, dengan ini penulis menyatakan bahwa desa Jogodayuh melaksanakan konsistensinya untuk mewujudkan pemberdayaan masyarakat secara berkelanjutan dengan adanya program ini sekaligus peningkatan kepuasan masyarakat.

2. Hasil evaluasi unsur kinerja sektor publik pada tahap berjalannya program yang cukup maksimal dengan tidak ada munculnya keluhan dari masyarakat dan pengawasan dari fasiliator BPUPK guna keberhasilan program. Masalah ditemukan setelah adanya proses serah terima pada pengelola sarana prasarana, dikarenakan kurangnya sumberdaya yang memadai dan dilihat dari sektor finansial, sehingga perlunya visi dalam setiap perencanaan.

3. Kepala Desa selaku pelindung sudah sangat transparan dalam memberikan arahan dan pemberian motivasi dalam berjalannya program guna mewujudkan kepuasan masyarakat. Sekaligus kemudahan peneliti dalam mengakses informasi yang berkaitan dengan kajian penelitian

\section{Saran}

Penulis memberikan saran yang mungkin dapat diterapkan pada pelaksana program PNPMMPd Desa Jogodayuh guna meningkatkan kepuasan terhadap masyarakat, berdasarkan pada evaluasi kinerja sektor publik sebagai berikut:

1. Perlu dilakukannya evaluasi bertahap setelah adanya program selesai dikerjakan, sebagai bahan untuk lebih meningkatkan kinerja pelaksana PNPM-MPd untuk periode selanjutnya.

2. Pemberian pelayanan sarana dan prasarana medis yang baik yang terdapat di Polindes sebagai bahan untuk membantu kesehatan masyarakat.

3. Pemberian sosialisasi kepada masyarakat yang lebih intensif mengenai dampak dari kredit yang dilakukan terhadap program PNPM-MPd. 


\section{DAFTAR PUSTAKA}

Burhan Bungin. 2011. Metodologi Penelitian Kuantitatif: Komunikasi, Ekonomi, dan Kebijakan Publik Serta Ilmu-Ilmu Sosial Lainnya. Jakarta: Kencana Prenada Media.

Deklarasi Dan Rekomendasi Temu Nasional PNPM Mandiri. 2008. Jakarta.

Deddi Nordiawan dan Ayuningtyas Hertanti. 2010. Akuntansi Sektor Publik. Jakarta: salemba Empat

Fandy Tjiptono. 2006. Pemasaran Jasa. Malang: Bayumedia Publishing.

Frederik Mote. 2008. Analisis Indeks Kepuasan Masyarakat (IKM) terhadap pelayanan publik di Puskesmas Ngesrep Semarang. Tesis diterbitkan. Semarang. UNDIP

Harbani Pasolong. 2008. Teori Administrasi Publik. Bandung. Alfabeta.

Harentama Fardhani. 2010. Analisis Faktor-Faktor Yang Mempengaruhi Kepuasan Masyarakat Pada Pelayanan Badan Pelayanan Perijinan Terpadu Kota Semarang. (http://eprints.undip.ac.id/26402/1/PENELITIAN FULL BARU plus ttd.pdf). Diunduh 29 Juni 2013.

Indra Bastian. 2005. Akuntansi Sektor Publik: suatu Pengantar. Jakarta: Erlangga

Lijan Poltak. 2012. Kinerja Pegawai Teori Pengukuran dan Implikasi. Yogyakarta: Graha Ilmu.

Mardiasmo. 2002. Akuntansi Sektor Publik. Yogyakarta. Andi Offset.

Mohammad Mahsun.2006. Akuntansi Sektor Publik. Yogyakarta. BPFE-Yogyakarta.

Mohammad Mahsun. 2013. Pengukuran Kinerja Sektor Publik. Yogyakarta. BPFEYogyakarta.

Pedoman Umum PNPM Mandiri. 2008. Jakarta

Philip Kotler dan Nancy Lee.2007. Pemasaran di Sektor Publik. Jakarta. PT INDEKS

Sri Lestari. 2012. Bantuan Sosial diIndonesia Sekarang Dan Kedepan. Bandung. Fokus Media.

Sugiyono. 2010. Metode penelitian pendidikan. Bandung. ALFABETA

Suharsimi Arikunto. 2010. Prosedur Penelitian: Suatu Pendekatan Praktik. Jakarta: Rineka Cipta. 